\title{
A Study of the Effects of Swedish Massage in a Multisensory Environment on the Health of Women in their 40 s and 50 s
}

\author{
Seongeun Oh \\ Department of Health and Cosmetics, Dongduk Women's University, Seoul, Korea
}

Corresponding author: Seongeun Oh, Department of Health and Cosmetics, Dongduk Women's University, 60 Hwarangro, 13-gil, Seongbuk-gu, Seoul 02748, Korea

Tel.: +82 29404261

Fax: +82 29404186

Email: 9641234@naver.com

Received July 13, 2021

Revised July 29, 2021

Accepted September 15, 2021

Published September 30, 2021

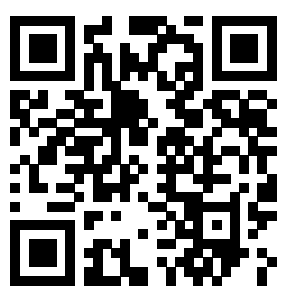

\begin{abstract}
Purpose: This study aimed to examine the physical and psychological effects of foot massage for middle-aged women in the snoezelen space. Methods: Participants were randomly divided into four groups of 30 persons each: the snoezelen foot massage group (MSE+FM, treatment group), general foot massage group (FM, comparison group I), snoezelen group (MSE, comparison group II), and untreated (CG, control group). The foot massage program was operated at snoezelen space for 30 min once, once a week, and four times for four weeks. Results: Muscle tone was lowest in the treatment group, followed by the comparison group I and comparison II; whereas, the control group appeared to have the highest $(F=52.686, p<0.001)$. Psychological stress was lowest in the treatment group, followed by the comparison group I and comparison II, while the control group appeared to have the highest $(F=141.428, p<0.001)$. Psychological well-being was highest in the treatment group, followed by the comparison group II, comparison group I, and control group $(F=428.022, p<0.001)$. The perceived health status was highest in the treatment group and comparison group I followed by comparison group II, and the control group $(F=224.395, p<0.001)$. Conclusion: The findings of the present study showed that Swedish foot massage alone are recognized as an excellent alternative therapy; however, it is thought that if the snoezelen space is mediated here, it will have a synergistic effect on physical and psychological improvement.
\end{abstract}

Keywords: Snoezelen space, Foot massage, Physical effect, Psychological effect, Alternative therapy

\section{Introduction}

중년 여성이란 일반적으로 연령이 40세에서 59 세 사이의 여성, 즉 노년기 이전 단계의 성숙한 여성을 의미한다(Kim et al., 2001). 중 년기 기혼여성은 가족 내에서의 역할과 관련된 압박감, 공허함과 죄 책감 등의 심리적 갈등을 경험한다. 자녀의 독립에 따른 가족의 재구 조화, 남성과 여성에 대한 역할 변화 등으로 인한 부부생활의 재 적 응기를 맞게 될 뿐 아니라, 노부모와 성인 자녀에 대한 이중 부양 부 담이 증가하는 시기이다(Kim et al., 2002; Bae \& Lee, 2020). 직장 여성은 직업적 성취도도 최고조에 이르는 반면 직업적 전환을 해야 하는 위기도 공존하는 시기이기 때문에, 직업으로 인한 긴장이 다른 시기보다 많은 편일 뿐 아니라, 다른 연령층보다 직업적 성취를 위한 열의가 가장 높기 때문에 성공에 대한 긴장도 높은 편이며 이를 위해
직장의 상사나 동료로부터 인정과 신임을 얻기 위한 시기이기도 하다 (Kang \& Seol, 2012).

중년 여성은 여성호르몬의 변화가 시작되어 갱년기를 겪거나 폐경 기를 맞게 되면서 성적 매력이 감소하고 자신의 아름다움과 생산능 력의 상실에 대한 갈등으로 인한 우울과 불안 등의 정서를 경험한다 (Choi \& Kim, 2018; Bang \& Choi, 2018). 이로 인해 여성이 남성 보다 더 심한 중년의 위기(mid-life crisis)를 경험할 수 있으며, Troll (1982)의 연구에서도 여성이 남성보다 자아실현의 문제 등으로 인한 위기감을 더 호소하고 있음을 밝혔다. 신체적으로도 큰 변화가 나타 나는 시기로 뇌졸중, 고혈압, 암, 심장질환 등의 성인병 및 골다공증, 안면홍조, 발한 등의 갱년기 질환이 발생한다(Lee \& Lee, 2017).

최근 건강보험심사평가원에서의 의료 빅데이터 분석 결과에 의하 면 폐경 및 갱년기로 진료를 받은 환자 수가 2015년 39만 3,837명, 
2016년 39만 7,073명, 2017년 39만 8,429명 등으로 지난 3년 동안 $9.8 \%$ 증가하였고, 2017년 여성 연령별 진료 인원을 살펴보면 50대 가 $61.5 \%$ 로 압도적으로 높고, 60 대(20.6\%), 40대(17.1\%) 순으로 나 타났다. 2019년 골다공증으로 병원을 찾은 여성은 102만여 명으로 남성(6만 300여 명)보다 16 배나 많다. 이 중 50세 이상 여성이 $95 \%$ 를 차지하였다. 폐경 전후에는 신체뿐 아니라 심리적 질환이 증가하 는데 지난해 병원을 방문한 우울증 환자는 여성이 남성보다 2 배 많았 고 이는 폐경으로 인한 상실감이 스트레스로 작용한 것으로 보인다고 하였다.

많은 선행연구에서 신체적, 심리적 문제를 줄이기 위한 방법으로 이완 요법이 제안되어 왔다(Chan et al., 2010; Deakin, 1995). 이완 이란, '긴장의 부재' 이거나 휴식 또는 심리적 이완의 불특정한 상태 를 의미한다. 정서적 안정감은 근육 이완과 공존하며, 정신적 긴장이 근육 긴장을 가져오기 때문에, 반대로 근육 긴장을 이완시킴으로써 결국에는 심리적 완화가 된다. 이는 부교감신경의 활성화로 정서적 흥분과 심리적 고통을 중화시키기 때문이다(Chan et al., 2010). 이 완 요법 중 $\mathrm{MSE}$ 테라피와 마사지의 단독 적용은 평형감, 심박수, 근 긴장도, 통증 등의 신체적 상태와 스트레스, 불안, 우울, 피로감 등의 심리적 상태를 개선하는데 긍정적 결과를 나타내는 거로 알려져 있다 (Kim \& Kim, 2014; Park et al., 2011).

Multi Sensory Environment (MSE)테라피는 시각, 후각, 청각, 촉 각, 미각 및 전정기관 등의 다감각을 자극하는 치료 환경으로 스노젤 렌이라도 한다(Lee \& Yoo, 2006). 특정 기술 훈련이 필요하지 않고, 과제로 인한 스트레스나 실패가 없으며, 일정 수준의 인지 및 의사소 통 능력을 요구하지 않는 것이 장점이다(Kokoszka, 1992).

스노젤렌 도입 초기에는 지적장애와 학습장애를 대상으로 한 연 구가 많았으나 최근에는 급성기 통증 환자, 조현병을 않는 환자, 치 매노인뿐만 아니라 임산부에 이르기까지 다양한 대상자로 확대되었 고 건축 영역까지 범위가 넓어졌다. 급성기 통증 환자에게 적용하 였을 때, 통증 지수가 현저하게 감소하였고, 수면 및 자기 효능감에 서도 유의한 개선을 보였으며(Schofield \& Davis, 1998), 출산을 하 는 임산부에게서도 통증이 감소하는 효과를 보였다(Manesh et al., 2015). 치매 환자에게서는 불안, 초조 및 치매의 심각도를 감소시켜 주는(Sánchez et al., 2016) 등 신체 및 심리에 효과가 있음이 검증되 었다.

지금까지 이완 요법으로써의 스노젤렌과 마사지의 단독 연구는 있 었지만 병용 연구는 소수로 존재하며 연구 대상도 임산부, 치매, 조 현병, 지적장애아 등의 환자 치료에 국한되어 왔다. 또한 스노젤렌 개별의 단독 효과를 비교하는 연구는 거의 없었다.

이에 본 연구는 스노젤렌공간에서 스웨디쉬 발마사지, 스웨디쉬 발마사지, 스노젤렌의 비교분석을 환자가 아닌 일반인을 대상으로 연구함으로써 향후 피부미용 분야의 실제적인 방향을 탐색한다는 점 에서 의미 있는 시도로 스노젤렌 스웨디쉬 발마사지가 중년 여성의 신체적 - 심리적 요인을 향상시킬 수 있다는 것을 평가하고자 한다.
스노젤렌 이라는 공간을 더 제품 지향적으로 개발하여 신체, 심리적 인 이완 상태를 즉각적으로 달성할 수 있는 효과적인 방법으로 활용 함으로써 중년 여성의 삶의 질을 향상시키고, 미용 분야의 연구 범위 를 확장 시키며, 실무적으로 에스테틱 산업 발전에 유용한 정보를 제 공할 수 있을 것으로 사료된다.

\section{Methods}

\section{1. 연구대상 및 실험방법}

연구 대상은 경기도 일부 지역에 거주하는 40-50대 중년 여성 120 명을 대상으로 2020년 9월 23일부터 2021년 3월 5일까지 스노젤렌 공 간에서 1 회 $30 \mathrm{~min}$, 주 1 회, 4 주간 총 4 회 스웨디쉬 발마사지를 실시하 였다.

스노젤렌 스웨디쉬 발마사지군 MSE+FM (처치군), 스웨디쉬 발마 사지군 FM (비교군 I), 스노젤렌군 MSE (비교군 II)및 무처치 CG (대 조군)의 네 그룹으로 구분하여 각 처치군 별로 30 명을 무작위 배정하였 다.

\section{2. 연구대상의 포함기준}

신체적, 심리적으로 비정상 범위에 속하는 자이며, 다음의 선정 기 준에 적합한 자로 하였다.

1) 포함기준

첫째, 평형감, 심박수 및 근긴장도로 측정된 신체적 상태 중 하나라 도 정상 범위를 벗어난 자

둘째, 각각의 심리검사(스트레스, 안녕감, 지각된 건강상태)를 통해 이상 소견이 나타난 자

이상 소견의 판단 기준은 다음과 같다.

(1)평형감 판단 기준(단위: $\mathrm{s}$ )

본 연구의 평형감 측정은 초(s) 단위로 측정하였으며, 시간이 길수록 평형감이 높음을 의미한다.

본 연구에서는 '14 s 미만'을 '저 평형감'으로 정의하였고, '24.6 s 이 상'을 '고 평형감'으로 하며 '저 평형감'과 '고 평형감'을 제외한 나머지 점 수 범위를 '보통 평형감'으로 정의하였다. 따라서 $14 \mathrm{~s}$ 미만이면 신체적 이상 소견이 나타난 자로 간주한다.

(2) 심박수 판단 기준(단위: $\mathrm{BPM}$ )

본 연구의 심박수 측정은 모바일 애플리케이션 'Cardiio'로 측정하였 으며, 분당 심박동수(beats per minute, $\mathrm{BPM}$ )를 나타낸 것으로 숫자가 클수록 심박수가 높음을 의미한다.

본 연구에서는 ' $60 \mathrm{BPM}$ 이하'를 '저 심박수'로 정의하였고, ' 80.1 $\mathrm{BPM}$ 이상'을 '고 심박수'로 하며 '저 심박수'와 '고 심박수'를 제외한 나 머지 점수 범위를 '보통 심박수'로 정의하였다. 따라서 $80.1 \mathrm{BPM}$ 이상 이면 신체적 이상 소견이 나타난 자로 간주한다(Shigetoh et al., 2009). 
(3) 근긴장도 판단 기준(단위: $\mathrm{Hz})$

본 연구의 근긴장도 측정은 'Myoton-Pro'로 측정하였으며, $1 \mathrm{~s}$ 동 안 진동한 횟수를 나타내는 것으로 숫자가 높을수록 근긴장도가 높음 을 의미한다.

본 연구에서는 ' $13 \mathrm{~Hz}$ 미만'을 '저 근긴장도'로 정의하였고, '18.1 $\mathrm{Hz}$ 이상'을 '고 근긴장도'로 하며 '저 근긴장도'와 '고 근긴장도'를 제 외한 나머지 점수 범위를 '보통 근긴장도'로 정의하였다. 따라서 18.1 $\mathrm{Hz}$ 이상이면 신체적 이상 소견이 나타난 자로 간주한다.

\section{(4) 심리적 스트레스 판단 기준}

본 연구의 스트레스 척도는 총 16 문항으로 구성되어 있으며(부록 참조), 각 영역별 스트레스 점수는 Likert 5점 척도(전혀 그렇지 않 다: 1점-매우 그렇다: 5 점)이다. 최저 16 점에서 최고 80 점까지 분포 하며, 점수가 높을수록 스트레스가 높음을 의미한다.

본 연구에서는 '전혀 그렇지 않다'와 '그렇지 않다'의 2 개 영역에 해 당되는 항목의 합계를 '저 스트레스'로 정의(16-32 점)하였고, '매우 그렇다'와 '그렇다'의 2 개 영역에 해당되는 항목의 합계를 '고 스트레 스'로 하며(64-80 점), '저 스트레스'와 '고 스트레스'를 제외한 나머지 점수 범위를 '보통 스트레스'로 정의(33-63 점) 하였다. 따라서 64점 이상이면 심리적 이상 소견이 나타난 자로 간주한다.

\section{(5) 심리적 안녕감 판단 기준}

본 연구의 심리적 안녕감 척도는 총 18 문항으로 구성되어 있으며 (부록 참조), 각 영역별 스트레스 점수는 Likert 5점 척도(전혀 그렇 지 않다: 1점-매우 그렇다: 5 점)이다. 최저 18점에서 최고 90 점까지 분포하며, 점수가 높을수록 심리적 안녕감이 높음을 의미한다.

본 연구에서는 '전혀 그렇지 않다'와 '그렇지 않다'의 2 개 영역에 해 당되는 항목의 합계를 '저 심리적 안녕감'으로 정의(18-36 점)하였 고, '매우 그렇다'와 '그렇다'의 2 개 영역에 해당되는 항목의 합계를 고 심리적 안녕감'으로 하며(72-90 점), '저 심리적 안녕감'과 '고 심 리적 안녕감'을 제외한 나머지 점수 범위를 '보통 심리적 안녕감'으로 정의(37-71 점) 하였다. 따라서 36점 이하면 심리적 이상 소견이 나 타난 자로 간주한다

\section{(6) 지각된 건강상태 판단 기준}

본 연구의 지각된 건강상태 척도는 총 4 문항으로 구성되어 있으며 (부록 참조), 각 영역별 스트레스 점수는 Likert 3점 척도(그렇지 않 다: 1점-그렇다: 3점)이다. 최저 4점에서 최고 12 점까지 분포하며, 점수가 높을수록 지각된 건강상태가 높음을 의미한다. 본 연구에서 는 '그렇지 않다' 영역에 해당되는 항목의 합계를 '저 지각된 건강상태' 로 정의(4-6 점)하였고, '그렇다' 영역에 해당되는 항목의 합계를 '고 지각된 건강상태'로 하며(10-12 점), '저 지각된 건강상태'와 '고 지각 된 건강상태'를 제외한 나머지 점수 범위를 '보통 지각된 건강상태'로 정의(7-9 점) 하였다. 따라서 6점 이하면 심리적 이상 소견이 나타난
자로 간주한다.

\section{3. 연구 절차}

\section{1) 스노젤렌 공간의 계획}

(1) 적용 시간 및 횟수

Park et al. (2011)은 스노젤렌 중재 연구에서 적용 방법 중 스노젤 렌의 중재 기간, 방문 주기, 중재 횟수, 적용 시간 등을 분석하였으며 본 연구에서는 중재 방법 중 가장 빈도수가 높은 것을 채택하여 적용 하였다.

\section{(2) 스노젤렌 공간구성}

O'Connor (1991)은 개인 치료실의 크기는 $3 \mathrm{~m} \times 3 \mathrm{~m}-4.8 \mathrm{~m} \times 4.8$ $\mathrm{m}$ 가 적당하다고 한바, 실제 크기는 가로 $3.6 \mathrm{~m}$, 세로 $4.2 \mathrm{~m}$ 로 하였 고, 스누젤렌의 벽과 천정은 빛의 효과를 더욱 두드러지게 하기 위 해 흰색을 사용하며, 여기에 시각적, 촉각적, 청각적, 후각적, 미각적 등 다감각적인 자극을 탐색할 수 있도록 하였다. 방 전체가 편안하게 느껴져야 하기 때문에 벽과 천정의 색은 매우 중요한 역할을 하고 있 고, 화려함보다는 아늑함을 우선한다.

\section{(3) 스노젤렌 자극 도구 구성}

2010년 10월 각국의 스노젤렌 전문가 8명의 토론 참여자들이 스 노젤렌 개념과 원칙, 보편적 framework 개발 및 가이드라인을 제 시(Pagliano, 2017)한 자극 도구를 사용하였다. 참여자가 스노젤렌 에 들어서면 물기둥, 미러볼, 별 커튼, 아로마 향기, 자연을 담은 음 악 등의 다양한 감각을 처음 느끼고, 테라피 의자까지의 경로엔 양모 매트, 면 시트와 면 쿠션의 부드러움을 접촉 하고 제공되는 오렌지가 미각세포를 자극한다. 스윙이 되는 테라피 의자에 앉아 다감각을 체 험하면서 $30 \mathrm{~min}$ 스웨디쉬 발마사지를 받으며 이때, 피부관리사와 참여자 간의 대화는 통제한다. 통제하지 않을 시 라포(rapport, 상호 신뢰관계 형성)에 의해 연구 결과가 달라질 수 있기 때문이다(Cho et al., 2019).

\section{2) 사전 검사}

스노젤렌 공간에서의 스웨디쉬 발마사지 프로그램 시작 전 신체 적, 심리적 상태 측정과 일반적 특성 및 동의서에 대한 자기 기재식 설문조사를 실시하였다.

3) 프로그램 처치

실험은 심리검사(스트레스, 안녕감, 지각된 건강상태)를 통해 이상 소견이 나타난 자와 평형감, 심박수 및 근긴장도로 측정된 신체적 상 태 중 하나라도 정상 범위를 벗어난 자 120 명을 선정하고 네 그룹으 로 구분하며 1 회 $30 \mathrm{~min}$ 으로 일주일에 1 회, 4 주간 총 4 회 동안 실시 하였다. 실험 중 수면은 통제하지 않는다.

(1) Multi sensory environment+Foot massage (MSE+FM)

$\mathrm{MSE}+\mathrm{FM}$ 군의 MSE+FM 프로그램(Table 1)은 스노젤렌 공간에 
서 스웨디쉬 발마사지를 받는 병용 형태이다. 참여자가 스노젤렌에 들어서면 물기둥, 미러볼, 별 커튼, 아로마 향기, 자연을 담은 음악 등의 다양한 감각을 처음 느끼고, 테라피 의자까지의 경로엔 양모 매 트, 면 시트와 면 쿠션의 부드러움을 접촉 하고 제공되는 오렌지가 미각세포를 자극한다. 스윙이 되는 테라피 의자에 앉아 다감각을 체 험하면서 $30 \mathrm{~min}$ 간 스웨디쉬 발마사지를 받으며 이때, 피부관리사와 참여자 간의 대화는 통제한다. 통제하지 않을 시 라포(rapport, 상호 신뢰관계 형성)에 의해 연구 결과가 달라질 수 있기 때문이다(Cho et al., 2019).

가장 효과적인 스노젤렌 프로그램은 스노젤렌 공간, 참여자 및 숙 련된 중재자 간의 상호작용일 때 3 방향 커뮤니케이션을 만들고, 효 과가 가장 극대화된다고 하였다. 또한 중재자와 참여자 간의 커뮤 니케이션은 대화를 의미하는 것이 아니라 터치에 의한 촉감을 의미 하며, 관리사들은 숙련도가 일정해야 한다(Haggar \& Hutchinson, 1991).

\section{(2) Foot massage (FM)}

$\mathrm{FM}$ 군의 $\mathrm{FM}$ 프로그램은 참여자가 피부 관리사에게 일반 피부 관 리실에서 스웨디쉬 발마사지를 받는 것으로, 1 년 이상 발마사지 경험 이 있고 숙련도가 같게끔 교육을 받은 피부관리사에 의해 스웨디쉬 발마사지를 조용한 방에서 $30 \mathrm{~min}$ 간 받게 된다. 마사지하는 동안 피 부의 마찰을 줄이기 위해 발 크림이 사용된다.

(3) Multi sensory environment (MSE)

$\mathrm{MSE}$ 군의 MSE 프로그램은 스노젤렌 공간에서 $30 \mathrm{~min}$ 간 휴식한다.

\section{(4) Control group (CG)}

대조군은 평소에 하던 일생 생활을 그대로 유지하고 발마사지를 포함한 다른 마사지 등을 통제한다. 통제하지 않을 시 신체적, 심리 적 호전으로 의해 연구의 결과가 달라질 수 있기 때문이다.

\section{5) 사후 검사}

사전검사와 같은 척도로 신체적 상태를 파악하기 위해 평형감, 심 박수 및 근긴장도의 재측정과 심리적 스트레스, 심리적 안녕감 및 지
각된 건강상태를 자기기재식으로 설문 조사하며, 대조군은 일주일에 1 번, 프로그램 처치 없이 신체적, 심리적 측정을 하였다.

\section{4. 측정 방법}

\section{1) 일반적 특성}

연구 대상자의 인구 사회적 특성은 구조화된 설문지로 연령, 교육 정도, 종교, 가족 구성원, 직업의 6 문항으로 구성되었다

\section{2) 신체적 측정도구}

(1) 평형감 (측정 단위: $\mathrm{s}$ )

평형감은 눈 감고 외발 서기 하는 것을 초침 시계로 측정하였다. 측정 방법은 편평한 바닥에 서서 양손을 허리에 고정시킨 후 오른 발을 들어 외발 서기를 하여 균형을 유지하도록 하였다. 시작 신호 와 함께 두 눈을 감고, 초침 시계를 사용하여 오른발 외발서기를 2 회 실시한 후 높은 측정치를 유지한 시간을 초로 기록하였다(Murray, 2016).

(2) 심박수(측정 단위: $\mathrm{Bpm}$ )

심박수를 측정하기 위해 사용한 도구는 스마트 앱인 'Cardiio'를 사 용하였다. 측정 방법은 앱을 설치하고 손가락을 아이폰 뒤쪽 카메라 에 대고 있으면 심박수가 측정된다. 체크하는 동안에는 움직이지 않 도록 한다. 정확한 분석과 통계를 구하기 위해 나이와 성별을 입력하 고 confirm을 터치한다. Cardiio Rhythm의 민감도와 특이도는 각각 $96.7 \%$ 와 $84.6 \%$ 로 발표되었다(Jeena, 2015).

(3) 근긴장도(측정 단위: $\mathrm{Hz}$ )

비복근의 근긴장도는 마이오톤(Myoton ${ }^{\circledR} \mathrm{PRO}$; MyotonAS, Estonia)를 이용하여 근긴장도(muscle tone)를 측정한다. 마이오톤 은 근기능의 특성을 간단하고 신속하며 정확하게 측정할 수 있는 장 비로써 높은 신뢰도가 보고 된 바 있다(Choi et al., 2017; Bower \& Murphy, 2016).

정확한 측정 수행을 위하여, 비복근(오금 중앙에서 수직 아래 12 $\mathrm{cm})$ 에 수술용 마커펜으로 표시하여 사전, 사후 동일한 곳을 측정하 였다. 대상자들은 편안하게 엎드린 자세에서 긴장감을 풀고 4 번 접은

\section{Table 1. Multi sensory environment and Foot massage program}

\begin{tabular}{lll}
\hline Stage & \multicolumn{1}{c}{ Sensory } & \\
Step 1 & Visual stimulation & Bubble tube, optical fiber, mirror ball and star curtains that lead to visual stimulation. \\
Step 2 & Auditory stimulation & Listening to music for therapy. (Tony O'Conner's Studio Horizon). \\
Step 3 & Olfactory stimulation & Exposure to incense using an aroma diffuser (Bergamot: Lavender: Ylang-Ylang=2:3:1). \\
Step 4 & Tactile stimulation & Feel the soft touch of the therapy chair, wool rugs, cotton cushions, and blankets. \\
Step 5 & Taste stimulation & Eat one slice of orange provided. \\
Step 6 & Vestibular stimulation & Relax body and mind sitting on a therapy chair. \\
Step 7 & Tactile stimulation by esthetician & Perform a Swedish foot massage for 15 minutes on each foot, starting with the right foot. \\
\hline
\end{tabular}


수건 위에 왼쪽 발을 올려놓는다. 검사자는 마커로 표시된 지점에 마 이오톤을 수직으로 하여 평가를 실시하며 1 회 평가 시 3 번의 타진을 통하여 평균값을 기록한다

3) 심리적 측정도구

(1)심리적 스트레스(16문항)

본 연구에서 심리적 스트레스를 측정하기 위해 한국 스트레스 매 니지먼트 연구소가 제작한 설문지를 사용하였다. 개발 당시의 신뢰 도인 Cronbach's $\alpha$ 는 0.89 (Lee \& Jeong, 2009)이었고, 본 연구에서 의 Cronbach's $\alpha$ 는 0.905 이다.

\section{(2)심리적 안녕감(18문항)}

리프(Ryff)가 개발한 심리적 안녕감 척도(psychological wellbeing scale)를 사용하였다. 개발 당시의 신뢰도인 Cronbach's $\alpha$ 는 0.80 이었고(Tuicomepee \& Romano, 2005), 본 연구에서의 Cronbach's $\alpha$ 는 0.887 이다.

\section{(3)지각된 건강상태(4문항)}

Lawton et al. (1982)이 개발한 Health Self Rating Scale을 사용 하였다. 도구 개발 당시 Cronbach's $\alpha$ 는 0.81이었고(Iecovich, 2011)

본 연구에서의 Cronbach's $\alpha$ 는 0.832 이다.

\section{5. 자료처리 및 분석}

본 연구에서 수집된 자료를 분석하기 위해 SPSS 26.0 을 사용하였 고 통계적 검정은 $5 \%$ 유의수준에서 실시하며, 적용되는 통계기법은 다음과 같다.

첫째, 연구 대상자의 일반적인 사항을 알아보기 위하여 기술 통계 와 각 문항에 대한 신뢰도를 알아보기 위하여 Cronbach's $\alpha$ 를 사용하 였다.

둘째, 스노젤렌 공간에서의 스웨디쉬 발마사지 프로그램을 실시하 기 전 처치군, 비교군 $\mathrm{I}$, 비교군 II, 대조군의 동질성 비교를 위해 $\chi^{2}$ 검정과 One-way ANOVA를 실시하였다.

셋째, 처치군, 비교군 I, 비교군 II, 대조군의 그룹 간 비교 분석을 위하여 one-way ANOVA와 사후 검정으로는 Ducan's test를 실시하 였다.

넷째, 각 그룹의 관리 전후에 대한 측정치를 비교하기 위하여 Paired $t$-test를 실시하였다.

다섯째, 처치군, 비교군 I, 비교군 II, 대조군의 반복측정 분석을 위하여 repeated measures ANOVA를 실시하였다.

\section{Results and Discussion}

\section{1. 그룹간의 일반적 특성 동질성 검증}

일반적인 특성에 대한 사전 동질성 비교 결과는 다음과 같이 종교 $\left(\chi^{2}=37.904, p<0.001\right)$, 가족 구성원 $\left(\chi^{2}=14.002, p<0.01\right)$ 를 제외한 연령, 교육 정도, 월평균 가계소득, 직업 변인별로 유의한 차이가 없 는 것으로 나타났다. 종교와 가족 구성원에 대한 동질성은 확인되지 않았지만 연구 결과 연령, 교육정도, 월평균 가계소득, 직업이 신체 및 심리적 효과에 미치는 영향은 없음으로, 네 그룹의 일반적 특성에 대한 동질성이 확보된 거로 간주하였다. 전체 응답자는 120 명이었 고, 일반적인 특성에 따른 분포는 다음과 같다(Table 2).

연령별로는 40대는 64 명(53.3\%), 50대는 56명(46.7\%), 교육 정도 는 고등학교 졸업은 40명(33.3\%), 대학교 졸업 이상은 78 명(65.0\%), 기타는 2 명(1.7\%)이었고, 종교는 기독교는 26 명 $(21.7 \%)$, 천주교는 42 명(35.0\%), 불교는 17명(14.2\%), 무교는 35명(29.2\%)이었으며, 월평균 가계소득은 600 만원 이상이 33 명(27.5\%), 600 만원 미만은 87 명 $(72.5 \%)$, 가족 구성원은 배우자와 동거는 57 명(47.5\%), 자녀들 과 동거는 63 명(52.5\%)이며, 직업별로는 가정주부는 87 명(72.5\%), 가정주부 외는 33 명 $(27.5 \%)$ 이었다.

\section{2. 그룹간의 요인별 동질성 검증}

처치군, 비교군 I, 비교군 II, 대조군의 평형감, 심박수, 근긴장도, 심리적 스트레스, 심리적 안녕감, 지각된 건강상태의 차이는 유의수 준 $5 \%$ 에서 유의미하지 않아, 네 군의 동질성이 검증되었다(Table 3 ).

\section{3. 관리 후 각 그룹의 효과성 비교}

4 회 관리 후 그룹의 효과성 비교는 다음과 같다(Table 4) 1)평형감

처치군 $(\mathrm{M}=36.5)$, 비교군 $\mathrm{I}(\mathrm{M}=36.0)$, 비교군 $\mathbb{I}(\mathrm{M}=37.3)$, 대조군 $(\mathrm{M}=35.2)$ 의 평균값이 비슷했으며, 유의한 차이는 없었다.

2)심박수

처치군 $(\mathrm{M}=73.1)$, 비교군 $\mathrm{I}(\mathrm{M}=73.6)$, 비교군 $\mathrm{I}(\mathrm{M}=73.0)$, 대조군 $(\mathrm{M}=73.2)$ 의 평균값이 비슷했으며, 유의한 차이는 없었다.

\section{3)근긴장도}

처치군(M=13.9), 비교군 $\mathrm{I}(\mathrm{M}=16.7)$, 비교군 $\mathbb{I}(\mathrm{M}=16.7)$, 대조 군 $(\mathrm{M}=18.2)$ 으로 처치군이 근긴장도가 가장 낮았고, 비교군 I 과 비 교군 II 가 다음순 이었고, 마지막 대조군으로 유의한 차이가 있었다 ( $F=52.686, p\langle 0.001$; Table 5).

실험 3 차부터 처치군에서 근긴장도의 효과가 나타나는데, 이는 스 노젤렌의 안전하고 편안한 환경을 제공하여 심신을 이완시키고, 더 나아가 이러한 환경에서의 발마사지가 근육 및 근막의 재배치를 활 성화시켜 나타난 결과로 판단되는데(Schneider et al., 2015), 이러한 결과는 스노젤렌 환경에 적응하여 심신이 이완되기 위해서는 이러한 환경을 신체가 인지하고 적응하는데 일정 기간이 필요한 것으로 유추 해 볼 수 있다.

중년 여성을 대상으로 등 경락마사지가 근긴장도 완화에 미치는 
Table 2. Test of homogeneity for general characteristics $(\mathrm{N}=120)$

Unit: N (\%)

\begin{tabular}{|c|c|c|c|c|c|c|c|c|}
\hline \multirow{2}{*}{\multicolumn{2}{|c|}{ Variable }} & \multirow{2}{*}{ N (\%) } & \multicolumn{4}{|c|}{ Group } & \multirow{2}{*}{$x^{2}$} & \multirow{2}{*}{$p$} \\
\hline & & & TG & CGI & CG II & $C G$ & & \\
\hline \multirow{2}{*}{ Age } & 40 's & $64(53.3)$ & 16(53.3) & $14(46.7)$ & $17(56.7)$ & $17(56.7)$ & \multirow{2}{*}{0.804} & \multirow{2}{*}{$0.84 \varsigma$} \\
\hline & 50 's & $56(46.7)$ & $14(46.7)$ & $16(53.3)$ & $13(43.3)$ & $13(43.3)$ & & \\
\hline \multirow{3}{*}{ Education level } & High school & 40(33.3) & 10(33.3) & $6(20.0)$ & $8(26.7)$ & 16(53.3) & \multirow{3}{*}{10.113} & \multirow{3}{*}{$0.12 C$} \\
\hline & Over college & $78(65.0)$ & 19(63.3) & $23(76.7)$ & $22(73.3)$ & 14(46.7) & & \\
\hline & Other & $2(1.7)$ & $1(3.3)$ & $1(3.3)$ & $0(0.0)$ & $\mathrm{O}(0.0)$ & & \\
\hline \multirow{4}{*}{ Religion } & Christianity & $26(21.7)$ & $6(20.0)$ & $4(13.3)$ & 4(13.3) & $12(40.0)$ & \multirow{4}{*}{$37.904^{* * *}$} & \multirow{4}{*}{0.000} \\
\hline & Catholic & $42(35.0)$ & $14(46.7)$ & 10(33.3) & $16(53.3)$ & $2(6.7)$ & & \\
\hline & Buddhism & $17(14.2)$ & $7(23.3)$ & $4(13.3)$ & $6(20.0)$ & $0(0.0)$ & & \\
\hline & Others & $35(29.2)$ & $3(10.0)$ & $12(40.0)$ & $4(13.3)$ & 16(53.3) & & \\
\hline \multirow{2}{*}{$\begin{array}{l}\text { Income } \\
\text { (1000 Won/Mon) }\end{array}$} & Over 600 & $33(27.5)$ & $8(26.7)$ & $9(30.0)$ & $10(33.3)$ & $6(20.0)$ & \multirow{2}{*}{1.463} & \multirow{2}{*}{0.691} \\
\hline & Under 600 & $87(72.5)$ & $22(73.3)$ & $21(70.0)$ & $20(66.7)$ & $24(80.0)$ & & \\
\hline \multirow{2}{*}{ Family member } & $\begin{array}{l}\text { Living with } \\
\text { spouse }\end{array}$ & $57(47.5)$ & $12(40.0)$ & $12(40.0)$ & $23(76.7)$ & 10(33.3) & \multirow{2}{*}{$14.002^{* *}$} & \multirow{2}{*}{0.003} \\
\hline & $\begin{array}{l}\text { Living with } \\
\text { children }\end{array}$ & $63(52.5)$ & 18(60.0) & 18(60.0) & $7(23.3)$ & $20(66.7)$ & & \\
\hline \multirow{2}{*}{ Job } & Housewife & $87(72.5)$ & $22(73.3)$ & $20(66.7)$ & $21(70.0)$ & $24(80.0)$ & \multirow{2}{*}{1.463} & \multirow{2}{*}{0.691} \\
\hline & Others & $33(27.5)$ & $8(26.7)$ & 10(33.3) & $9(30.0)$ & $6(20.0)$ & & \\
\hline
\end{tabular}

TG, treatment group; CG I, comparative group I ; CG II, comparative group II ; CG, control group.

Table 3. Verification the similarity of the physical \& psychological condition before experiment

\begin{tabular}{|c|c|c|c|c|c|c|}
\hline \multirow[b]{2}{*}{ Group } & \multicolumn{3}{|c|}{ Physical condition } & \multicolumn{3}{|c|}{ Psychological condition } \\
\hline & Equilibrium & Heart rate & Muscle tone & Psychological stress & $\begin{array}{l}\text { Psychological } \\
\text { well-being }\end{array}$ & $\begin{array}{l}\text { Perceptived } \\
\text { health status }\end{array}$ \\
\hline TG & $32.7 \pm 15.71^{1)}$ & $72.3 \pm 4.06$ & $18.5 \pm 0.95$ & $3.8 \pm 0.30$ & $2.5 \pm 0.16$ & $1.4 \pm 0.26$ \\
\hline CG I & $33.2 \pm 14.25$ & $73.6 \pm 4.47$ & $18.6 \pm 0.87$ & $3.7 \pm 0.20$ & $2.6 \pm 0.13$ & $1.4 \pm 0.20$ \\
\hline CG II & $34.1 \pm 14.72$ & $73.6 \pm 4.27$ & $18.2 \pm 1.08$ & $3.8 \pm 0.23$ & $2.5 \pm 0.14$ & $1.4 \pm 0.22$ \\
\hline CG & $31.7 \pm 15.85$ & $73.0 \pm 4.56$ & $18.1 \pm 1.04$ & $3.8 \pm 0.25$ & $2.5 \pm 0.17$ & $1.4 \pm 0.30$ \\
\hline $\mathrm{F}(p)$ & $0.123(0.946)$ & $0.579(0.630)$ & $1.685(0.174)$ & $0.982(0.404)$ & $2.362(0.075)$ & $0.075(0.973)$ \\
\hline
\end{tabular}

TG, treatment group; CG I, comparative group I ; CG II, comparative group II ; CG, control group.

${ }^{11}$ The data were expressed as mean \pm standard deviation.

Table 4. Verification of the physical \& psychological condition after experiment

\begin{tabular}{|c|c|c|c|c|c|c|}
\hline \multirow[b]{2}{*}{ Group } & \multicolumn{3}{|c|}{ Physical condition } & \multicolumn{3}{|c|}{ Psychological condition } \\
\hline & Equilibrium & Heart rate & Muscle tone & Psychological stress & $\begin{array}{l}\text { Psychological } \\
\text { well-being }\end{array}$ & $\begin{array}{l}\text { Perceptived } \\
\text { health status }\end{array}$ \\
\hline TG & $36.5 \pm 14.83^{1)}$ & $73.1 \pm 4.26$ & $13.9 \pm 1.27$ & $2.5 \pm 0.20$ & $4.2 \pm 0.19$ & $2.8 \pm 0.20$ \\
\hline CG I & $36.0 \pm 14.07$ & $73.6 \pm 4.87$ & $16.7 \pm 1.55$ & $2.9 \pm 0.20$ & $3.7 \pm 0.25$ & $2.8 \pm 0.19$ \\
\hline CG ॥ & $37.3 \pm 14.59$ & $73.0 \pm 4.08$ & $16.7 \pm 1.55$ & $2.9 \pm 0.29$ & $3.8 \pm 0.18$ & $2.5 \pm 0.19$ \\
\hline CG & $35.2 \pm 15.43$ & $73.2 \pm 4.14$ & $18.2 \pm 1.01$ & $3.7 \pm 0.22$ & $2.6 \pm 0.10$ & $1.5 \pm 0.31$ \\
\hline$F(p)$ & $0.107(0.956)$ & $0.138(0.937)$ & $52.686^{* * *}(0.000)$ & $141.428^{* * *}(0.000)$ & $428.022^{* * *}(0.000)$ & $224.398^{* * *}(0.000)$ \\
\hline Duncan & & & $\mathrm{TG}<\mathrm{CG} \|, \mathrm{CG} I<\mathrm{CG}$ & $\mathrm{TG}<\mathrm{CG} \|, \mathrm{CG} I<\mathrm{CG}$ & $\mathrm{CG}<\mathrm{CG} \mid<\mathrm{CG} \|<\mathrm{TG}$ & $\mathrm{CG}<\mathrm{CG} \|<\mathrm{CG}$ I, TG \\
\hline
\end{tabular}

TG, treatment group; CG I, comparative group I ; CG II, comparative group II ; CG, control group.

${ }^{1)}$ The data were expressed as mean \pm standard deviation. ${ }^{* * *} p<0.001$. 
효과를 비교한 Yun \& Shin (2012)의 연구에서 마사지 처치 후 근긴 장도가 유의하게 감소하였다는 결과를 제시하였는데, 이러한 결과는 중년 여성의 근긴장도를 완화시키는 데 있어서 등 경락마사지 처치가 효과가 있다는 것을 의미하며, 본 연구에서 나타난 중년 여성 근긴장 도 완화의 발마사지 처치 효과와 같은 경향을 보이고 있음을 알 수 있 다. 또한, 스노젤렌 처치와 근긴장도 완화 효과를 연구한 Hotz et al. (2006)은 트라우마 증상을 겪고 있는 아이들을 대상으로 스노젤렌 처 치에 따른 근긴장도의 변화를 실험적으로 연구하였는데, 그 결과 스 노젤렌 환경 처치를 통해 근긴장도를 완화시키는데 유의한 효과가 있 음을 실험적으로 밝힌 바 있다. 따라서 이상의 선행연구들은 본 연구 의 결과와 일치하는 경향을 보이며, 본 연구의 결과를 지지하고 있음 을 알 수 있다.

\section{4)심리적 스트레스}

처치군 $(\mathrm{M}=2.5)$, 비교군 $\mathrm{I}(\mathrm{M}=2.9)$, 비교군 $\mathbb{I}(\mathrm{M}=2.9)$, 대조군 $(\mathrm{M}=3.7)$ 으로 처치군이 가장 심리적 스트레스가 낮았고, 비교군 I 과 비교군 II 가 다음 순 이었고, 마지막 대조군으로 유의한 차이가 있었 다 $(F=141.428, p<0.001$; Table 6).

실험 3차부터 처치군에서 심리적 스트레스의 효과가 현저히 나타 나는데, 이는 일관되게 유지되는 스노젤렌 환경이 단조로움을 유발 하여 일반적인 각성을 낮춰줌으로써 스트레스 해소에 도움을 주었다 는 것을 의미한다. 특히 스노젤렌은 심리적인 효과가 높아지기 위해 서는 그러한 상황에 대한 예측이 가능해야만 단조로움과 지루함으로 각성이 낮추어질 수 있는데(Grealish et al., 2000), 스노젤렌 환경에
대해 실험 3 차부터 예측이 가능한 상황에 대한 결과로 유추해 볼 수 있다.

본 연구의 결과는 발마사지가 심리적 스트레스 완화에 유의미한 효과가 있음을 실증적으로 제시한 Lee (2011)의 연구 결과와도 일치 함으로써 본 연구의 결과를 지지하고 있다.

또한, 정신적 스트레스를 받는 중년 여성 27 명을 대상으로 마사지 처치에 따른 스트레스 완화 효과를 비교한 $\operatorname{Kim} \& \operatorname{Han}$ (2010)의 연 구에서는 총 10 회의 마사지 처치를 통해 유의미한 정신적 스트레스 의 완화 효과가 있음을 실증적으로 제시하였다. Jang et al. (2009) 또한 스웨디시 마사지 처치에 따른 스트레스 완화 효과를 비교한 결과를 제시함으로써 본 연구와 맥을 같이 하고 있다. Han \& Jun (2009)은 40-60세 여성 20명을 대상으로 발 반사마사지 처치에 따 른 중년 여성의 스트레스 완화 효과를 비교하였는데, 그 결과 총 10 회의 발 반사마사지 처치를 통해 유의미한 스트레스의 완화 효과가 있음을 실증적으로 제시함으로써 앞선 선행연구들과 마찬가지로 본 연구의 결과를 지지하고 있음을 알 수 있다.

한편, 스노젤렌 처치의 스트레스 완화 효과를 실증 분석한 Jang et al. (2008)은 대학생들을 대상으로 스노젤렌 처치에 따라 이들 대학 생들의 스트레스 완화에 긍정적 효과가 있음을 실증적으로 규명하였 는데, 조사대상이 중년 여성이 아닌 20대 대학생들을 대상으로 하였 으나, 이러한 결과로부터 중년 여성의 스트레스를 완화하기 위한 스 노젤렌 처치의 효과를 확인한 본 연구의 결과와 일치하는 경향을 보 인다고 볼 수 있다. 또한, Collier et al. (2018)은 직장인 16명을 대상 으로 스노젤렌 처치에 따른 심리적 스트레스의 변화를 실험적으로 연

Table 5. Muscle tone's repeated measures ANOVA

\begin{tabular}{lccccc}
\hline Variable & Baseline & 1st & 2nd & 3rd & 4th \\
TG & $18.5 \pm 0.95^{1)}$ & $16.5 \pm 0.82$ & $16.7 \pm 0.92$ & $16.2 \pm 1.35$ & $13.9 \pm 1.27$ \\
CG I & $18.6 \pm 0.87$ & $16.9 \pm 0.88$ & $16.8 \pm 0.82$ & $16.7 \pm 0.68$ & $16.7 \pm 1.55$ \\
CG II & $18.2 \pm 1.08$ & $17.2 \pm 0.88$ & $16.9 \pm 0.94$ & $16.8 \pm 0.94$ & $16.7 \pm 1.55$ \\
CG & $18.1 \pm 1.04$ & $17.8 \pm 1.27$ & $17.7 \pm 1.29$ & $17.9 \pm 1.21$ & $18.2 \pm 1.01$ \\
$F(p)$ & $1.685(0.174)$ & $8.509^{* * *}(0.000)$ & $6.496^{* * *}(0.000)$ & $13.836^{* * *}(0.000)$ & $52.686^{* * *}(0.000)$ \\
Duncan & & TG<CG II<CG & TG, CG II, CG I<CG & TG $<$ CGIl<CG & TG<CG II, CG I<CG \\
\hline
\end{tabular}

TG, treatment group; CG I, comparative group I ; CG II, comparative group II ; CG, control group.

${ }^{1)}$ The data were expressed as mean \pm standard deviation. ${ }^{* * *} p<0.001$.

\section{Table 6. Psychological stress's repeated measures ANOVA}

\begin{tabular}{lccccc}
\hline Variable & Baseline & 1st & 2nd & 3rd & 4th \\
TG & $3.8 \pm 0.30^{1)}$ & $3.9 \pm 0.27$ & $3.6 \pm 0.29$ & $2.9 \pm 0.38$ & $2.9 \pm 0.38$ \\
CG I & $3.7 \pm 0.20$ & $3.4 \pm 0.26$ & $3.4 \pm 0.23$ & $3.3 \pm 0.19$ & $3.3 \pm 0.19$ \\
CG II & $3.8 \pm 0.23$ & $3.5 \pm 0.28$ & $3.3 \pm 0.20$ & $3.3 \pm 0.19$ & $3.3 \pm 0.19$ \\
CG & $3.8 \pm 0.25$ & $3.9 \pm 0.30$ & $3.7 \pm 0.18$ & $3.7 \pm 0.21$ & $3.7 \pm 0.21$ \\
$F(p)$ & $0.982(0.404)$ & $21.010^{* * *}(0.000)$ & $24.093^{* * *}(0.000)$ & $41.947^{* * *}(0.000)$ & $141.428^{* * *}(0.000)$ \\
Duncan & & CG II, CG I<CG, TG & CG II, CG I<CG, TG & TG $<$ CG II, CG I<CG & TG<CG II, CG I<CG \\
\hline
\end{tabular}

TG, treatment group; CG I, comparative group I ; CG II, comparative group II ; CG, control group.

${ }^{11}$ The data were expressed as mean \pm standard deviation. ${ }^{* * *} p<0.001$. 
구하였는데, 그 결과 스노젤렌 환경 처치는 직장인들의 심리적 스트레 스를 완화시키는데 유의한 효과가 있음을 실험적으로 밝힌 바 있다. 따라서 이상의 선행연구들은 본 연구의 결과와 일치하는 경향을 보이 며, 본 연구의 결과를 지지하고 있음을 알 수 있다.

\section{5) 심리적 안녕감}

처치군 $(\mathrm{M}=4.2)$, 비교군 $\mathrm{I}(\mathrm{M}=3.7)$, 비교군 $\mathbb{I}(\mathrm{M}=3.8)$, 대조군 $(\mathrm{M}=2.6)$ 으로 처치군이 가장 심리적 안녕감이 높았고, 다음으로 비교 군 II, 비교군 I 순으로 높았고, 대조군이 가장 낮은 것으로 나타났으 며, 유의한 차이가 있었다 $(F=428.022, p<0.001$; Table 7).

Ryan \& Deci (2001)은 청소년들을 대상으로 발마사지 처치에 따른 심리적 안녕감 증진 효과를 비교하였는데, 그 결과 총 2 주간의 발마사 지 처치를 통해 유의미한 심리적 안녕감 증진 효과가 있음을 실증적으 로 제시함으로써 본 연구의 결과와 일치하는 경향을 보이고 있다. 또 한, Sansone \& Schmitt (2000)은 35세-44세 전업주부 31명을 대상 으로 아로마테라피 마사지 처치에 따른 심리적 안녕감 증진 효과를 비 교하였는데, 총 10 회의 아로마테라피 마사지 처치를 통해 이들 여성 들의 심리적 안녕감이 유의하게 높게 나타난 실증 분석 결과를 제시함 으로써 심리적 안녕감 증진에 있어서 아로마테라피 마사지 처치가 효 과적임을 확인함으로써 본 연구의 결과를 지지하고 있다.

한편, 스노젤렌 처치에 따른 심리적 안녕감 증진효과를 비교한 Nielsen \& Overgaard (2020)는 14명의 여성들을 대상으로 스노젤렌 처치에 따른 심리적 안녕감의 변화에 대하여 질적 연구를 수행하였는 데, 그 결과 스노젤렌 환경 처치는 조사대상 여성들의 심리적 안녕감
을 증진시키는데 유의한 효과가 있음을 실험적으로 밝힌 바 있다. 6)지각된 건강상태

처치군(M=2.8), 비교군 $I(M=2.8)$, 비교군 $I(M=2.5)$, 대조군 $(\mathrm{M}=1.5)$ 으로 처치군, 비교군 I 이 지각된 건강상태가 높았고, 다음으 로 비교군 II 순으로 높았고, 대조군이 가장 낮았으며, 유의한 차이가 있었다 ( $F=224.395, p<0.001$; Table 8).

발마사지 처치를 통해 불안을 감소시켜주고, 기분 상태, 안위감이 나 건강해진다는 인식에 긍정적인 효과가 있음을 보고한 바 있는 Won (2002)의 연구 결과와 본 연구의 결과는 서로 맥을 같이 하고 있다. Won (2002)의 연구에서는 노인들을 대상으로 총 6 회 발마사지 처치 를 수행함으로써 이들이 지각하는 건강증진 효과를 분석하였으며 분 석 결과, 발마사지가 수면의 질과 피로를 개선시켜 활력감을 주고 이 로 인해 지각된 건상상태의 증진 효과가 있음을 제시한 본 연구의 결 과와 일치한다. 발마사지는 마사지를 받는 사람의 신체적 이완과 심리 적인 이완을 유도함으로써 심신의 균형을 가져오고, 사람의 심리적 상 태와 기분은 신체의 모든 영역에 영향을 미치게 된다는 점에 비추어 볼 때 사람의 오감을 긍정적으로 자극함으로써 심리적 상태와 기분을 좋게 하여 건강에 대한 지각이 긍정적으로 인식되는 것으로 이해할 수 있다(Won, 2002). 한편, Palmore \& Luikart (1972)는 65세 이상 장년 층을 대상으로 오감을 편안하게 자극하는 스노젤렌 테라피가 이들의 지각된 건강에 어떠한 영향을 미치는지를 살펴보았는데, 그 결과 스노 젤렌 처치를 받은 65 세 이상 대상자들은 자신의 건강이 향상된 느낌 을 받은 것으로 나타남으로써 본 연구의 결과와 일맥상통하는 결과로 써 본 연구의 결과를 뒷받침하고 있다.

Table 7. Psychological well-being's Repeated Measures ANOVA

\begin{tabular}{|c|c|c|c|c|c|}
\hline Variable & Baseline & 1st & 2nd & $3 r d$ & 4th \\
\hline TG & $2.5 \pm 0.16$ & $3.0 \pm 0.32$ & $3.7 \pm 0.25$ & $4.0 \pm 0.24$ & $4.2 \pm 0.19$ \\
\hline CG I & $2.6 \pm 0.13$ & $3.3 \pm 0.18$ & $3.4 \pm 0.26$ & $3.4 \pm 0.27$ & $3.7 \pm 0.25$ \\
\hline CG ॥ & $2.5 \pm 0.14$ & $3.3 \pm 0.15$ & $3.4 \pm 0.26$ & $3.5 \pm 0.29$ & $3.8 \pm 0.18$ \\
\hline $\mathrm{CG}$ & $2.5 \pm 0.17$ & $2.6 \pm 0.11$ & $2.6 \pm 0.13$ & $2.6 \pm 0.12$ & $2.6 \pm 0.10$ \\
\hline$F(p)$ & $2.362(0.075)$ & $78.984^{* * *}(0.000)$ & $145.125^{* * *}(0.000)$ & $164.708^{* * *}(0.000)$ & $428.022^{* * *}(0.000)$ \\
\hline Duncan & & $\mathrm{CG}<\mathrm{TG}<\mathrm{CG}$ II, CG I & $\mathrm{CG}<\mathrm{CG} \|, \mathrm{CG} I<\mathrm{TG}$ & $\mathrm{CG}<\mathrm{CG} \|, \mathrm{CG} I<\mathrm{TG}$ & $\mathrm{CG}<\mathrm{CG} \|<\mathrm{CG} \quad \mid<\mathrm{TG}$ \\
\hline
\end{tabular}

TG, treatment group; CG I, comparative group I ; CG II, comparative group II ; CG, control group.

${ }^{1)}$ The data were expressed as mean \pm standard deviation. ${ }^{* * *} p<0.001$.

\section{Table 8. Perceptived health status's repeated measures ANOVA}

\begin{tabular}{|c|c|c|c|c|c|}
\hline Variable & Baseline & $1 s t$ & 2nd & $3 r d$ & 4th \\
\hline $\mathrm{TG}$ & $1.4 \pm 0.26^{1)}$ & $1.8 \pm 0.29$ & $2.3 \pm 0.26$ & $2.6 \pm 0.23$ & $2.8 \pm 0.20$ \\
\hline CG I & $1.4 \pm 0.20$ & $2.0 \pm 0.25$ & $2.2 \pm 0.24$ & $2.7 \pm 0.21$ & $2.8 \pm 0.19$ \\
\hline CG ॥ & $1.4 \pm 0.22$ & $1.8 \pm 0.28$ & $2.1 \pm 0.23$ & $2.3 \pm 0.24$ & $2.5 \pm 0.19$ \\
\hline CG & $1.4 \pm 0.30$ & $1.4 \pm 0.27$ & $1.4 \pm 0.24$ & $1.4 \pm 0.20$ & $1.5 \pm 0.31$ \\
\hline$F(p)$ & $0.075(0.973)$ & $25.742^{* * *}(0.000)$ & $86.032^{* * *}(0.000)$ & $203.196^{* * *}(0.000)$ & $224.398^{* * *}(0.000)$ \\
\hline Duncan & & $\mathrm{CG}<\mathrm{CG}$ II, TG<CG I & $C G<C G \|<T G$ & $\mathrm{CG}<\mathrm{CG} \|<\mathrm{CG}$ I, TG & CG $<$ CG $\|<C G I, T G$ \\
\hline
\end{tabular}

TG, treatment group; CG I, comparative group I ; CG II, comparative group II ; CG, control group.

${ }^{1)}$ The data were expressed as mean \pm standard deviation. ${ }^{* * *} p<0.001$. 


\section{Conclusion}

본 연구를 통해 기존의 스웨디쉬 발마사지가 심리적 상태와 신체 적 상태에 미치는 효과를 규명함과 더불어 스노젤렌 처치 또한 중년 여성들의 심리적 상태와 신체적 상태에 긍정적인 효과가 있음을 밝힐 수 있었다. 또한, 발마사지 단일 처치의 효과와 스노젤렌 단일 처치 의 효과보다 발마사지와 스노젤렌을 병행 처치하였을 때, 그 효과가 극대화됨을 밝혔다는 점에서 본 연구의 의의가 있다고 볼 수 있다. 따라서 본 연구의 결과는 기존 피부 관리실에서 피부 관리공간을 스 노젤렌 환경으로 조성함으로써 피부관리 효과를 극대화시킬 수 있음 을 시사하고 있으며, 추후 실제 스노젤렌에 대한 인식이 확산됨에 따 라 에스테틱 현장에 적용되어 활용될 것으로 기대된다.

This work is Seong-Eun Oh's M.S. thesis at the Dongduk Women's University, Seoul, Korea.

\section{Author's contribution}

SEO designed all experimental investigations, and wrote manuscript. All figures are created by the author.

\section{Author details}

Seongeun Oh (Graduate Student), Department of Health and Cosmetics, Dongduk Women's University, 60 Hwarangro, 13-gil, Seongbuk-gu, Seoul 02748, Korea.

\section{References}

Bae MN, Lee MS. Phenomenological study on volunteer experiences in auriculotherapy for middle-aged women. Asian Journal of Beauty and Cosmetology, 18: 27-39, 2020.

Choi YE, Kim YJ. Effects of soybean diet and back massage on the neck skin of middle-aged women. Asian Journal of Beauty and Cosmetology, 16: 533-544, 2018.

Bang HJ, Choi IH. Effects of a cosmetic psychotherapy program using an integrated approach with counseling and meridian massage on Hwa-byung relief for middleaged women. Asian Journal of Beauty and Cosmetology, 16: 52-61, 2018.

Chan AAYH, David Stahlman W, Garlick D, Fast CD, Blumstein DT, Blaisdell AP. Increased amplitude and duration of acoustic stimuli enhance distraction. Animal Behaviour, 80: 1075-1079, 2010.
Cho EH, Song HE, Yoo DH. The trend of overseas studies on the intervention of multisensory environment. The Journal of Korean Academy of Sensory Integration, 17: 54-64, 2019.

Cho J, Lim J, Kim MK, Kim JJ. Effects of new conceptual microcurrent stimulation therapy on muscle function of gastrocnemius. Archives of Orthopedic and Sports Physical Therapy, 13: 53-60, 2017.

Han CJ, Jun HY. The effect of foot reflexology on stress decrease in Korean middle-aged women. Asian Journal of Beauty and Cosmetology, 7: 37-45, 2009.

Collier L, Mcpherson K, Elis-Hil C, Staal J, Bucks R. Multisensory stimulation to improve functional performance in moderate to severe dementia-interim results. American Journal of Alzheimer's Disease and Other Dementias, 25: 698-703, 2010.

Deakin $\mathrm{M}$. Using relaxation techniques to manage disruptive behaviour. Nursing Times, 91: 40-41, 1995.

Grealish L, Lomasney A, Whiteman B. Foot massage. A nursing intervention to modify the distressing symptoms of pain and nausea in patients hospitalized with cancer. Clinical Trial, 23: 237-243, 2000.

Haggar LE, Hutchinson RB. Snoezelen: an approach to the provision of a leisure resource for people with profound and multiple handicaps. British Journal of Learning Disabilites, 19: 51-55, 1991.

Hotz AG, Castelblance A, Lara IM, Weiss AD, Duncan R, Kuluz JW. Snoezelen: a controlled multi-sensory stimulation therapy for children recovering from severe brain injury. Brain Injury, 20: 879-888, 2006.

lecovich E. Quality of relationships between care recipients and their primary caregivers and its effect on caregivers' burden and satisfaction in Israel. Journal of Gerontological Social Work, 54: 570-591, 2011.

Jang C, Song MO, Bae JS, Kim EJ, Son HY, Min EJ, Kim JH, Park $\mathrm{KH}$. The effects of snoezelen on the stress and attention for college students. The Journal of Korean Society of Health Sciences, 5: 57-74, 2008.

Jang JH, Doh EJ, Kim KW. A study on the influence of highfrequency therapy and swedish massage upon the alleviation of trapezius muscle pain and stress. Asian Journal of Beauty and Cosmetology, 7: 121-130, 2009.

Kang JH, Seol YW. A qualitative study of unmarried middleaged women's perceptions and preparation efforts for 
successful aging. Korean Journal of Family Welfare, 17: 127-151, 2012.

Kim GB, Yoo JH, Lee EJ. The experience of middle-aged women's crisis. Journal of Korean Academy of Nursing, 32: 305-316, 2002.

Kim SJ, Han CJ. Effect of decreasing on stress, depression and climacteric symptoms using the rose and clarysage essential oil body massage in Korean middle-aged women. Asian Journal of Beauty and Cosmetology, 8: 1-10, 2010.

Kim SS, Kim HN. The effect of swedish massage to the health index of the mid-aged women. Journal of the Korean Society of Esthetic \& Cosmeceutics, 9: 123-132, 2014.

Kim YI, Kim NI, Chio KS, Kim DJ. The effect of percent body fat on pulmonary function in adult obese women. Korean Journal of Physical Education, 40: 877-886, 2001.

Kokoszka A. Relaxation as an altered state of consciousness. International Journal of Psychosomatics, 39: 4-9, 1992.

Lee HJ, Lee KH. The effect of aromatherapy program on the stress and mood of the middle aged women's generation. Journal of the Korean Society of Cosmetology, 23: 12711278, 2017.

Lee JY, Yoo EY. The effects of implementation of multisensory environments (snoezelen) on the emotional state of college students. Korean Journal of Occupational Therapy, 14: 39-47, 2006.

Lee KG, Jeong GP. The effect of taekwondo training on stress response, blood lactate, body composition, aerobic and anaerobic capacity in women. The Korean Journal of Sport Studies, 18: 819-828, 2009.

Lee YM. Effects of self-foot reflexology on stress, fatigue, skin temperature and immune response in female undergraduate students. Journal of Korean Academy of Nursing, 14: 110-118, 2011.

Lawton MP, Moss M, Fulcomer M, Kleban MH. A research and service oriented multilevel assessment instrument. Journal of Gerontology, 37: 91-99, 1982.

Manesh MJ, Kalti M, Hosseini F. Snoezelen room and childbirth outcome. Iranian Red Crescent Medical Journal, 17: e18373, 2015.

Murray MM, Lewkowicz DJ, Amedi A, Wallace MK. Multisensory processes: a balancing act across the lifespan. Trends in Neurossciences, 39: 567-579, 2016.

Nielsen $\mathrm{JH}$, Overgaard C. Healing architecture and snoezelen in delivery room design: a qualitative study of women's birth experiences and patient centeredness of care. $B M C$ Pregnancy and Childbirth, 20: 283, 2020.

O'Connor K. The play therapy primer. John Wiley \& Sons, New York, pp308-319, 1991.

Pagliano P. Multisensory environments. David Fulton Publishers, New York, pp52-93, 2017.

Palmore E, Luikart C. Health and social factors related to life satisfaction. Journal of Health and Social Behavior, 13: 68-69, 1972.

Sánchez A, Maseda A, MArante-Moar MP, de Labra C, LorenzoLopez L, Millán-Calenti JC. Comparing the effects of multisensory stimulation and individualized music sessions on elderly people with severe dementia. Journal of Alzheimer's Disease, 52: 303-315, 2016.

Sansone P, Schmitt L. Providing tender touch massage to elderly nursing home residents: a demonstration project. Geriatic Nursing, 21: 303-308, 2000.

Schneider S, Peipsi A, Stokes M, Knicker A, Abeln V. Feasibility of monitoring muscle health in microgravity environments using Myoton technology. Medical \& Biological engineering \& Computing, 53: 57-66, 2015.

Schofield P, Davis B. Sensory deprivation and chronic pain: a review of the literature, 20: 357-366, 1998.

Shigetoh Y, Adachi H, Yamagishi S, Enomoto M, Fukami A, Otsuka M, Kumagae S, Furuki K, Nanjo Y, Imaizumi T. Higher heart rate may predispose to obesity and diabetes mellitus. American Journal of Hypertension, 22: 151-155, 2009.

Troll LE. Continuations: adult development and aging. Brooks/ Cole, Monterey, CA, pp1-34, 1982.

Tuicomepee A, Romano JL. Psychological well-being of Thai drug users: implications for prevention. International Journal for the Advancement of Counselling, 27: 431444, 2005.

Ryan RM, Deci EL. On happiness and human potentials: a review of research well-being. Annual Review of Psychology, 52: 141-166, 2001.

Won JS. Effect of foot massage on sleep, vital sign and fatigue in the elderly who live in their home. Journal of Korean Academy of Fundamentals of Nursing, 9: 513-523, 2002.

Park YR, Oh DN, Kim KS, Kim JA. The analysis of intervention studies for snoezelen. The Korean Journal of Rehabilitation Nursing, 14: 95-102, 2011. 
Yun SJ, Shin MH. The effect of back meridian massage on the muscle tension and body heat change of CLBP (chronic low back pain) middle-aged women. Journal of the Korean Society of Cosmetology, 18: 771-776, 2012. 


\section{국문초록}

\section{다감각환경에서의 스웨디쉬 발마사지가 40,50 대 여성 건강에 미치는 효과}

오성은

동덕여자대학교 보건향장학과, 서울, 한국

목적: 본 연구는 40,50 대 중년 여성을 대상으로 다감각환경(스노젤렌) 공간에서의 스웨디쉬 발마사지를 통한 신체 및 심리효과를 분석하기 위한 목적으로 수행되었다. 방법: 스노젤렌 발마사지군 MSE+FM (처치군), 일반 발마사지군 FM (비교군 I ), 스노젤렌군 $\mathrm{MSE}$ (비교군 II)및 무처치 CG (대조군)의 네 그룹으로 구분하여 각 처치군 별로 30명을 무작위 배정하였다. 결과: 근긴장도는 처치 군, 비교군 I , 비교군 II, 대조군으로 처치군이 근긴장도가 가장 낮았고, 비교군 I 과 비교군 II 가 다음순 이었고, 마지막 대조군으로 유의한 차이가 있었다 ( $F=52.686, p\langle 0.001)$. 심리적 스트레스는 처치군, 비교군 I , 비교군 II, 대조군)으로 처치군이 가장 심리적 스 트레스가 낮았고, 비교군 I 과 비교군 II 가 다음순 이었고, 마지막 대조군으로 유의한 차이가 있었다( $F=141.428, p<0.001)$. 심리적 안녕감은 처치군, 비교군 I, 비교군 II, 대조군으로 처치군이 가장 심리적 안녕감이 높았고, 다음으로 비교군 II, 비교군 I 순으로 높았고, 대조군이 가장 낮은 것으로 나타났으며, 유의한 차이가 있었다 $(F=428.022, p<0.001)$. 지각된 건강상태는 처치군, 비교군, 비교군 II, 대조군으로 처치군, 비교군 I 이 지각된 건강상태가 높았고, 다음으로 비교군 II 순으로 높았고, 대조군이 가장 낮았으며, 유의한 차이가 있었다( $F=224.395, p<0.001)$. 결론: 이러한 결과를 통해 스웨디쉬 발마사지만으로도 훌륭한 대체요법으로 인정받고 있지만, 여기에 스노젤렌공간을 중재한다면 신체 및 심리적 개선에 시너지 효과를 낼 것으로 사료된다. 따라서, 스노젤렌이라는 공 간을 좀 더 제품 지향적으로 개발하여 신체, 심리적으로 이완 상태를 즉각적으로 달성할 수 있는 효과적인 방법으로 활용함으로써 중년 여성의 삶의 질을 향상시키고, 미용 분야의 연구 범위를 확장 시키며, 실무적으로 에스테틱 산업 발전에 유용한 정보를 제공할 수 있을 것으로 기대한다.

핵심어: 스노젤렌 공간, 발마사지, 신체적 효과, 심리적 효과, 대체요법

\section{참고문헌}

강정희, 설연욱. 중년독신여성의 성공적 노화에 대한 인식과 준비에 대한 질적 연구. 한국가족복지학지, $17: 127-151$, 2012.

김귀분, 유재희, 이은자. 중년 여성의 위기 경험. Journal of Korean Academy of Nursing, 32: 305-316, 2002. 김성자, 한채정. 로즈와 클라리세이지 에센셜 오일을 이용한 전신마사지가 중년여성의 스트레스, 우울 척도 및 갱년기 증 상 완화에 미치는 영향. 아시안뷰티화장품학술지, 8: 1-10, 2010.

김소순, 김해남. 스웨디쉬 마사지가 중년여성의 건강지수에 미치는 영향. 한국피부미용향장학회지, 9: 123-132, 2014. 김영일, 김남익, 최건식, 김덕중 중년의 비만여성에서 체지방율이 안정시 호흡기능에 미치는 영향. 한국체육학회지, $40:$

877-886, 2001.

박영례, 오두남, 김금순, 김진아, 위휘. 스노젤렌 중재연구 논문분석. 재활간호학회지, 14: 95-102, 2011.

방해주, 최인혁. 미용심리치료 프로그램이 중년여성의 화병 완화에 미치는 효과. 아시안뷰티화장품학술지, 16: 52-61, 2018.

배미녀, 이명선, 중년여성의 이혈(耳穴)자원봉사 경험에 대한 현상학적 연구. 아시안뷰티화장품학술지, 18: 27-39, 2020.

원종순 발마사지가 노인의 수면, 활력징후, 피로에 미치는 영향. 기본간호학회지, 9: 513-523, 2002.

윤신중, 신명희. 등경락마사지가 CLBP (Chronic Low back pain) 중년 여성의 근 긴장도 및 체열변화에 미치는 영향. 한

국미용학회지, 18: 771-776, 2012. 
이영미. 자가발반사요법이 여대생의 스트레스, 피로, 피부온도 및 면역 반응에 미치는 효과. 대한간호학회지, 14: 110118, 2011.

이강구, 정근표. 태권도 운동이 성인 여성의 스트레스 반응, 젖산피로도, 신체구성, 유산소능력과 무산소능력에 미치는 영

향. 한국체육과학회지, 18: 819-828, 2009.

이지연, 유은영. 스트레스 관리접으로서의 다감각환경 (스노젤렌) 적용이 정서 상태에 미치는 영향. 대한작업치료학회지, 14: 39-47, 2006.

이희정, 이경희 아로마테라피 프로그램이 중년여성의 스트레스와 기분에 미치는 효과. 한국미용학회지, 23: 1271-1278, 2017.

장재희, 도은정, 김고운 스웨디시 사지와 고주파요법이 승모근 통증과 스트레스 완화에 미치는영향. 대한피부미용학회지, 7: 121-130, 2009.

장철, 송민옥, 배진숙, 김은정, 손희영, 민은주, 김정혜, 박경희 스노젤 렌이 대학생의 스트레스와 집중력에 미치는 영향. 대한건강과학학회지, 5: 57-74, 2008.

조은희, 송현은, 유두한. 다감각환경중재에 관한 국외 연구의 경향. 대한감각통합치료학회지, 17: 54-64, 2019.

조재진, 임종민, 김모경, 김효범, 김정진. 신 개념 미세전류 자극치료의 적용이 장딴지근의 근기능에 미치는 영향. 정형스 포츠물리치료학회지, 13: 53-60, 2017.

진재영 금신호 서정근. 유래한 리날룰오일 마사지가 전업주부의 혈액 및 타액 Cortisol, DHEA 및 IgA 변화에 미치는 효 과. 인간식물환경학회지, 17: 255-260, 2014.

최은영, 김윤정. 청국장 식이와 등 마사지가 중년여성의 목 피부에 미치는 영향. 아시안뷰티화장품학술지, $16: 533-544$, 2018.

한채정, 전혜영 발 반사마사지가 중년 여성의 스트레스 완화에 미치는 영향. 아시안뷰티화장품학술지, $7: 61-70,2009$. 


\section{中文摘要}

\section{多感觉环境中的Swedish足部按摩对40、50岁女性健康的效果}

吳誠恩

同德女子大学保健香妆学科，首尔，韩国

目的: 本研究以40,50岁中年女性为对象, 通过多感觉(史露西伦)环境中的Swedish脚底按摩来分析身体和心理 效果。方法：参与者被随机分为四组, 每组30人： snoezelen足底按摩组（MSE+FM, 治疗组）、普通足底按 摩组（FM，比较组I）、snoezelen组（MSE，比较组II）和未治疗组（CG，对照组）。在snoezelen空间进行 足部按摩, 每次30分钟, 每周一次, 四次, 持续四周。结果: 治疗组肌张力最低, 其次为比较组和比较组II; 然而, 对照组出现了最高值 $(F=52.686, p<0.001)$ 。 心理压力在治疗组最低, 其次是比较组 $\mid$ 和比较组 II, 而 对照组似乎最高 $(F=141.428, p<0.001)$ 。心理健康状况在治疗组最高, 其次是比较组II、比较组和对照组 $(F=428.022, p<0.001)$ 。认知健康状况在治疗组和比较组I中最高, 其次是比较组川和对照组 $(F=224.395$, $p<0.001 ）$ 。结论: 本研究结果表明, 瑞典足部按摩单独被认为是一种优秀的替代疗法; 然而, 人们认为, 如果 在这里调节鼻孔间隙，它将对身体和心理的改善产生协同效应。

关键词: 史露西伦，足部按摩，生理效果，心理效果，替代疗法 